\title{
Genetic associations with asthma and virus-induced wheezing: a systematic review*,*
}

\author{
Associação genética da asma e da sibilância \\ induzida por vírus: uma revisão sistemática
}

\author{
Leonardo Araujo Pinto, Renato Tetelbom Stein, José Dirceu Ribeiro
}

\begin{abstract}
Various wheezing phenotypes can be identified based on differences in natural histories, risk factors and responses to treatment. In epidemiologic studies, atopic asthma or virus-induced wheezing can be discriminated by the presence or the absence of sensitization to allergens. Children with asthma have been shown to present lower levels of lung function. Patients with viral respiratory infections evolve from normal lung function to enhanced airway reactivity. The objective of this study was to identify genes and polymorphisms associated with different wheezing phenotypes. Using data obtained from the Genetic Association Database, we systematically reviewed studies on genes and polymorphisms that have been associated with virus-induced wheezing or atopic asthma. The research was carried out in February of 2009. Genes associated with the studied outcomes in more than three studies were included in the analysis. We found that different genes and loci have been associated with virus-induced wheezing or atopic asthma. Virus-induced wheezing has frequently been associated with $I L-8$ polymorphisms, whereas atopic asthma and atopy have frequently been associated with Th2 cytokine gene (CD14 and $l L-13$ ) polymorphisms on chromosome 5. This review provides evidence that different wheezing disorders in childhood can be differently affected by genetic variations, considering their role on airway inflammation and atopy. Future studies of genetic associations should consider the different wheezing phenotypes in infancy. In addition, stratified analyses for atopy can be useful for elucidating the mechanisms of the disease.
\end{abstract}

Keywords: Genetics; Polymorphism, genetic; Asthma; Interleukins; Respiratory syncytial viruses.

\section{Resumo}

Diversos fenótipos de sibilância têm sido identificados com base em diferenças na história natural, fatores de risco e resposta ao tratamento. Em estudos epidemiológicos, a asma atópica ou sibilância induzida por vírus pode ser discriminada pela presença ou ausência de sensibilização a alérgenos. As crianças com asma apresentam níveis menores de função pulmonar. Pacientes com infecções respiratórias virais apresentam-se com função pulmonar normal, mas mostram reatividade da via aérea aumentada. 0 objetivo deste trabalho foi identificar genes e polimorfismos associados aos diferentes fenótipos de sibilância. Utilizando dados do Genetic Association Database, foi realizada uma revisão sistemática de estudos sobre genes e polimorfismos associados à sibilância induzida por vírus ou à asma atópica. 0 levantamento foi realizado em fevereiro de 2009. Todos os genes associados com o desfecho estudado presentes em mais de três estudos foram incluídos na análise. ldentificamos que diferentes genes e locos têm sido associados à sibilância induzida por vírus ou à asma atópica. Enquanto a sibilância induzida por vírus foi mais frequentemente associada a polimorfismos no gene $l L-8$, polimorfismos localizados em genes de citocinas Th2 no cromossomo 5 (CD14 e $l L-13)$ foram frequentemente associados à atopia ou à asma atópica. Esta revisão mostrou evidências de que a sibilância na infância pode ser afetada por variações genéticas de formas diferentes, dependendo de seu papel na inflamação das vias aéreas e na atopia. Estudos futuros de associação genética deverão levar em consideração os diferentes fenótipos na infância. Além disso, análises estratificadas para atopia podem ser úteis para elucidar os mecanismos da doença.

Descritores: Genética; Polimorfismo genético; Asma; Interleucinas; Vírus sinciciais respiratórios.

\footnotetext{
* Study carried out at the Centro de Investigação em Pediatria - CIPED, Pediatrics Investigation Center - Universidade Estadual de Campinas - Unicamp, State University at Campinas - Campinas, Brazil, and at the Instituto de Pesquisas Biomédicas - IPB, Biomedical Research Institute - Pontifícia Universidade Católica do Rio Grande do Sul - PUCRS, Pontifical Catholic University of Rio Grande do Sul - Porto Alegre, Brazil.

Correspondence to: Leonardo A. Pinto. Instituto de Pesquisas Biomédicas, Hospital São Lucas/PUCRS, Av. Ipiranga, 6690, $2^{\circ}$ andar, CEP 90610-000, Porto Alegre, RS, Brasil.

Tel/Fax 5551 3384-5104. Email: leonardo.pinto@pucrs.br

Financial support: None.

Submitted: 31 March 2009. Accepted, after review: 31 July 2009.

** A versão completa em português deste artigo está disponível em www.jornaldepneumologia.com.br
} 


\section{Introduction}

Although wheezing is highly prevalent in infants and children in the first six years of life, only certain children develop persistent atopic asthma later in life. ${ }^{(1)}$ Diverse wheezing phenotypes can be identified based on differences in risk factors, natural histories and responses to treatment. ${ }^{(2-3)}$ International guidelines, which are based on the efficacy of systemic corticosteroids in reducing hospitalization in children with classic atopic asthma, recommend the use of oral corticosteroids for children with virusinduced wheezing who present to a hospital. However, the results of trials that have addressed the question of efficacy of systemic corticosteroids in young children with acute wheezing are contradictory. Atopic wheezing and non-atopic wheezing have contrasting natural histories and can have different etiologies. Atopic asthma has been associated with an allergic or eosinophilic response in older patients with asthma. ${ }^{(4)}$ However, in young children with virus-induced wheezing, neutrophils typically predominate in BAL fluid samples. ${ }^{(5)}$

In various epidemiologic studies, ${ }^{(6-7)}$ children with atopic asthma have been shown to present positive skin prick test results and increased airway responsiveness as major associated risk factors. Among such children, there is a significant association between an early onset of wheezing and the severity of the disease. Children with atopy have been shown to present lower levels of lung function by three years of age. (8) For preschool children with wheezing, early allergic sensitization increases the prevalence of respiratory symptoms, airway inflammation and the risk of asthma being diagnosed later in life. Several studies have shown that asthma during childhood is strongly associated with elevated serum $\lg$ E and positive skin prick test results. ${ }^{(9-11)}$ Early sensitization to allergens is associated with an increased risk for the development of bronchial hyperresponsiveness. ${ }^{(12)}$ Elevated lgE levels at nine months of age correlates directly with the risk of persistent wheezing, suggesting a form of $\operatorname{lgE}$-mediated sensitization during the first years of life. ${ }^{(13)}$ Children who had asthma by seven years of age were sensitized very early in life and had persistent sensitization when compared with children who did not have asthma. ${ }^{(14)}$ These findings indicate that a genetic predisposition for atopy is associated with asthma symptoms that start early in life and persist into adulthood.

Lower respiratory illnesses (LRIs) caused by viral infection can also be associated with persistent wheezing in infants and preschool children. Non-atopic wheezers evolve from normal lung function to slightly impaired lung function and enhanced airway reactivity later in childhood. Stein et al. ${ }^{(15)}$ examined the relationship between LRIs in infants and the subsequent development of wheezing during the first decade of life. The authors found that most wheezing episodes are due to viral respiratory infections, with respiratory syncytial virus (RSV) being detected in the majority of these episodes. Analyses demonstrated that RSV infections in infancy were associated with an increased risk of wheezing during the first ten years of life, regardless of other known risk factors for asthma or asthma-related symptoms, such as family history of asthma or atopy. However, RSV-induced wheezing has not been associated with an increased risk of atopy or higher serum $\lg$ E levels.

Children who had virus-induced wheezing early in life were more likely to have lower levels of lung function at eleven years of age when compared with controls. One can suggest that, in some children, the viral infection led to a specific inflammatory response that caused this long-term airway obstruction. Therefore, a significant number of children who present wheezing during the first decade of life do so in association with viral respiratory agents regardless of atopy. This wheezing phenotype seems to be associated with wheezing that is less severe. Among school-age children in developed countries, this phenotype is probably less prevalent than is the atopic phenotype, although this might not hold true in different environments. Findings from developing countries ${ }^{(16)}$ have led to the hypothesis that different risk factors, such as recurrent or severe viral aggressions, are associated with an increased expression of this wheezing phenotype that is not associated with atopy. Genetic variants in the genes associated with the immune response can be associated with either non-atopic forms of wheezing or atopic asthma. Unless the atopic and non-atopic forms of wheezing are analyzed separately, the effects might not be detected. 


\section{Data collection}

The Genetic Association Database (GAD) is an archive of human genetic association studies of complex disorders, organized by the National Institute of Health (http://geneticassociationdb. nih.gov/). This database allows researchers to identify relevant polymorphisms from the large volume of gene variations, in the context of a standardized nomenclature for genes and polymorphisms. The database includes selected published scientific papers. Study data are recorded with the official nomenclature used for the human genome. The submitted records are reviewed before their inclusion in the database. ${ }^{(17)}$ In the present study, we searched the $\mathrm{GAD}$, employing the following search terms: "virus and asthma"; "respiratory syncytial virus"; "asthma and atopy"; and "atopy". All searches were performed in February of 2009. Genes that were associated with the studied outcomes in more than three studies were included in the analysis.

\section{Genetic associations with atopic asthma and virus-induced asthma}

The number of studies identified for each term was the following: 2 for "virus and asthma"; 15 for "respiratory syncytial virus"; 9 for "asthma and atopy"; and 79 for "atopy". The 9 studies related to asthma and atopy were grouped together with those related to atopy alone. In addition, the 2 papers related to virus and asthma were grouped together with those related to RSV. Genes that were associated with the studied outcomes in more than three studies were further reviewed. Viral or specifically RSV-induced wheezing was associated with polymorphisms in $I L-8$ in 4 different studies (Chart 1). Single nucleotide polymorphisms (SNPs) located on Th2 genes positioned on chromosome 5 (CD14 and $I L-13$ ) and chro- mosome $16(/ L-4 R)$ were associated with atopy or atopic asthma in 16 studies (CD14 in 5, $/ L-13$ in 4 and $l L-4 R$ in 7 , Chart 2).

Studies on Th2 cytokines and their relationship with asthma have focused on $I L-4$ and $l L-13$. This is due to the crucial role of these two cytokines in the generation of Th2 responses: $1 \mathrm{~L}-4$ is essential for the maturation of naive $\mathrm{T}$ cells towards Th2 cells and the production of $\operatorname{lgE}$; and $\mathrm{lL}-13$ is a protein product that shares several biological profiles with $1 \mathrm{~L}-4$, including $\operatorname{lgE}$ production and $\mathrm{MHC}$ class 11 expression. ${ }^{(18-21)}$ However, $1 \mathrm{~L}-8$ is a chemokine that has been associated preferentially with virus-induced inflammation and is one of the major mediators of the inflammatory response. It is secreted by several cell types and functions as a chemoattractant factor, especially for neutrophils. In addition, $I L-8$ is believed to play a role in the pathogenesis of bronchiolitis, a common respiratory tract disease in infants caused by viral infections. ${ }^{(22,23)}$ Considering these data, $l L-8$ and other members of the chemokine gene family can be considered relevant candidate genes for non-atopic forms of wheezing in childhood.

\section{Genetics of atopic asthma}

Studies of twins have shown the importance of the genetics in asthma variance, with estimated heritability ranging from $48 \%$ to $79 \%$. One important finding is that most of these twin studies in different parts of the developed world showed similar and consistent results and suggest that atopic asthma, in particular, has a strong genetic background. Although we can estimate to what extent genetic susceptibility contributes to the risk of asthma and atopy, all specific loci that influence this clinical phenotype are far from being clearly determined. Although a significant number of genetic association studies have described atopy susceptibility genes, these data

Chart 1 - Genes associated with virus-induced wheezing in more than three genetic studies.

\begin{tabular}{|c|c|c|c|c|}
\hline Gene & Phenotype & Chr & Chr and band & Reference \\
\hline$I L-8$ & RSV-induced wheezing & 4 & $4 q 13-q 21$ & Hull et al..$^{(32)}$ \\
\hline$I L-8$ & RSV-induced wheezing & 4 & $4 q 13-q 21$ & Puthothu et al. ${ }^{(34)}$ \\
\hline$I L-8$ & RSV-induced wheezing & 4 & $4 q 13-q 21$ & Heinzmann et al. ${ }^{(31)}$ \\
\hline IL-8 & RSV infection & 4 & $4 q 13-q 21$ & Lu et al. ${ }^{(35)}$ \\
\hline
\end{tabular}

Chr: chromossome; and RSV: respiratory syncytial virus. 
Chart 2 - Genes associated with atopic asthma or atopy in more than three genetic studies.

\begin{tabular}{|c|c|c|c|c|}
\hline Gene & Phenotype & $\mathrm{Chr}$ & Chr and band & Reference \\
\hline$C D 14$ & Atopy (total lgE)) & 5 & $5 q 22-q 32$ & Leung et al. ${ }^{(36)}$ \\
\hline$C D 14$ & Atopy & 5 & $5 q 22-q 32$ & Buckova et al. (37) \\
\hline$C D 14$ & Atopy & 5 & $5 q 22-q 32$ & Kabesch et al. ${ }^{(38)}$ \\
\hline$C D 14$ & Atopy & 5 & $5 q 22-q 32$ & Leynaert et al.(39) \\
\hline CD14 & Atopy & 5 & $5 q 22-q 32$ & Koppleman et al. ${ }^{(40)}$ \\
\hline$I L-13$ & Atopy & 5 & $5 q 31$ & Liu et al. ${ }^{(41)}$ \\
\hline$I L-13$ & Atopy (specific lgE) & 5 & $5 q 31$ & Leung et al. ${ }^{(42)}$ \\
\hline$I L-13$ & Asthma and atopy & 5 & $5 q 31$ & Howard et al..$^{(43)}$ \\
\hline$I L-13$ & Atopy & 5 & $5 q 31$ & Nieters et al ${ }^{(44)}$ \\
\hline$I L-4 R$ & Atopy & 16 & $16 p 11-12$ & Ober et $\mathrm{al}^{(45)}$ \\
\hline$I L-4 R$ & Atopy & 16 & $16 p 11$ & Liu et al..$^{(41)}$ \\
\hline$I L-4 R$ & Atopy (lgE) & 16 & $16 p 11$ & Heinzmann et al. ${ }^{(19)}$ \\
\hline$I L-4 R$ & Atopy & 16 & $16 p 11$ & Nieters et al. ${ }^{(44)}$ \\
\hline$I L-4 R$ & Atopy & 16 & $16 p 11$ & Deichmann et al. ${ }^{(46)}$ \\
\hline$I L-4 R$ & Atopic asthma & 16 & $16 p 11$ & Isidoro-Garcia et al. ${ }^{(47)}$ \\
\hline$I L-4 R$ & Asthma and atopy & 16 & $16 p 11$ & Kruse et al. ${ }^{(48)}$ \\
\hline
\end{tabular}

Chr: chromossome; and lL-4R: lL-4 receptor.

demonstrate the extreme complexity of the trait, and the identification of these polymorphisms presents a considerable challenge.

Several candidate genes have been studied in atopic disorders, and different factors contribute to this abundance of candidates. Results from genome screens have provided evidence of linkage to multiple sites in the genome. Therefore, there are candidate genes at many positions. In addition, immunological pathways associated with the allergic response involve a large array of inflammatory mediators. However, the best replicated results in genetic association studies of atopic asthma involve the human genome regions 5q31-32 and 16p11-12 (Chart 2).

There is evidence that Th2 genes located on chromosome $5 q(I L-13$ and $l L-4)$ are major determinants of atopic asthma. In addition, IL-13 encodes an immunoregulatory cytokine produced primarily by activated Th2 cells, and this cytokine promotes $\lg \mathrm{E}$ isotype switching. Furthermore, 1L-13 inhibits the production of pro-inflammatory chemokines. This cytokine is found to be critical to the pathogenesis of allergen-induced asthma. The $I L-13$ and $I L-4$ genes form a cytokine gene cluster on chromosome $5 \mathrm{q}$. It has been reported that the promoter SNP rs1800925 of the $l L-13$ gene contributes significantly to bronchial hyperresponsiveness and susceptibility to atopic asthma. ${ }^{(18)}$ Heinzmann et al. ${ }^{(19)}$ determined that a coding SNP of $I L-13$ (rs20541) is associated with asthma in case-control populations; the variant also predicted asthma and higher serum IL-13 levels in a Japanese population. The protein encoded by the $I L-4$ gene is a Th2 cytokine produced by activated $T$ cells that influence the allergic immune response. The lL-4 receptor also binds to IL-13, which might contribute to overlapping functions of $1 \mathrm{~L}-4$ and $1 \mathrm{~L}-13$. It has also been suggested that SNPs in the $l L-4$ gene are involved in the development of asthma and the regulation of total serum $\operatorname{lgE} .{ }^{(20)}$ Our group has shown ${ }^{(21)}$ that the combined analyses of genetic alterations in the $1 \mathrm{~L}-4 / 1 \mathrm{~L}-13$ pathway reveal their significance for the development of atopy and childhood asthma. Moreover, other genes harbored at the same loci, such as CD14, might contribute to asthma and allergy.

The $1 \mathrm{~L}-4$ receptor $(I L-4 R)$, on chromosome $16 p$, is a key component in the induction of Th2 lymphocytes. A further role that IL-4 plays in the pathogenesis of asthma has been indicated from sensitized il-4 knockout mice. Neither specific $\lg$ E induction nor bronchial hyperreactivity was detected in these mice, suggesting a critical role for the $1 \mathrm{~L}-4 / 1 \mathrm{~L}-4 \mathrm{R}$ pathway in these phenotypes. At least 16 SNPs in the lL-4RA gene have been reported. The coding polymorphisms $150 \mathrm{~V}$, S478P, and Q551R have been associated with a greater risk of atopy, a greater risk of atopic asthma, and variations in lgE levels. ${ }^{(18)}$ 


\section{Genetics and mechanisms of virus-induced asthma}

The important role of $1 \mathrm{~L}-8$ in the pathophysiology of bronchial inflammation has been confirmed by studies in humans and animals. Administration of 1L-8 into the airways induces bronchial hyperreactivity in pigs ${ }^{(22,23)}$ and increased levels of 1L-8 in sputum precede wheezing exacerbation in humans. ${ }^{(24)}$ In addition, lL-8 might be especially important in non-atopic wheezing, since lL-8-producing cells are more frequently found in this subgroup of patients with asthma. ${ }^{(25)}$ Furthermore, $1 \mathrm{~L}-8$ selectively inhibits $\lg$ E production in atopic patients by inhibiting lL-4 and thus might even protect against the development of atopy. ${ }^{(26,27)}$

The RSV is involved in at least $70 \%$ of the cases of bronchiolitis and has been repetitively linked to wheezing. It has been hypothesized that severe RSV infections in infancy might be associated with the development of recurrent wheezing or bronchitis. ${ }^{(28,29)}$ According to the current evidence, genetic and environmental factors determine the type of immune response to RSV infections. Furthermore, this response might affect the development of control mechanisms in the regulation of airway diseases.

Increased concentrations of 1L-8 have been described in BAL fluid and sputum of patients with recurrent wheezing. ${ }^{(30)}$ In addition, a genetic association of lL-8 has been described with both persistent wheezing ${ }^{(31)}$ and RSV bronchiolitis. ${ }^{(32,33)}$ Heinzmann et al. ${ }^{(31)}$ demonstrated an association between polymorphisms in $/ L-8$ with bronchial asthma. Furthermore, the findings suggested that RSV bronchiolitis and asthma have at least some different genetic factors: the same promoter polymorphism in $I L-8$ that causes susceptibility to RSV bronchiolitis might protect against asthma. The results might suggest a distinct and even opposite role of 1L-8 in atopic and non-atopic wheezing. Further studies provide evidence of a genetic susceptibility determinant for RSV bronchiolitis. ${ }^{(31-35)}$ In a genetic association analyses, they investigated a SNP located-251 nt relative to the $l L-8$ transcriptional start site. Hull et al. showed a trend for increased $1 \mathrm{~L}-8$ production in association with the $1 \mathrm{~L}-8-251 \mathrm{~A}$ allele when blood is stimulated with LPS. ${ }^{(32)}$ Analysis of cases of RSV bronchiolitis showed that the IL-8-251A allele is significantly associated with the severity of the disease. The effect was most marked for severe disease requiring oxygen therapy for more than two days, and for cases of bronchiolitis with no other known risk factors.

\section{Final considerations}

This review demonstrated different effects of genetic variations in atopic ${ }^{(36-48)}$ and non-atopic wheezing. ${ }^{(31-35)}$ These differences should be interpreted considering the role of these genes on airway inflammation and atopy. Although these phenotypes can have different etiologies, no clinical index or test for the differentiation between atopic asthma and viral wheezing has proven sufficiently accurate to be useful in young children. However, future genetic association studies should systematically investigate the wheezing phenotypes separately. Such studies could identify clinical relevant genetic markers of virus-induced wheezing or atopic asthma.

\section{References}

1. Martinez FD, Wright AL, Taussig LM, Holberg CJ, Halonen M, Morgan WJ. Asthma and wheezing in the first six years of life. The Group Health Medical Associates. N Engl J Med. 1995; 332(3):133-8.

2. Stein RT, Martinez FD. Asthma phenotypes in childhood: lessons from an epidemiological approach. Paediatr Respir Rev. 2004; 5(2):155-61.

3. Illi S, von Mutius E, Lau S, Niggemann B, Grüber C, Wahn $\mathrm{U}$, et al. Perennial allergen sensitisation early in life and chronic asthma in children: a birth cohort study. Lancet. 2006;368(9537):763-70. Erratum in: Lancet. 2006;368(9542):1154.

4. Bousquet J, Chanez P, Lacoste JY, Barnéon G, Ghavanian $\mathrm{N}$, Enander l, et al. Eosinophilic inflammation in asthma. N Engl J Med. 1990;323(15):1033-9.

5. Le Bourgeois M, Goncalves M, Le Clainche L, Benoist MR, Fournet JC, Scheinmann P, et al. Bronchoalveolar cells in children $<3$ years old with severe recurrent wheezing. Chest. 2002;122(3):791-7.

6. Sears MR, Greene JM, Willan AR, Wiecek EM, Taylor DR, Flannery EM, et al. A longitudinal, populationbased, cohort study of childhood asthma followed to adulthood. N Engl J Med. 2003;349(15):1414-22.

7. Morgan WJ, Stern DA, Sherrill DL, Guerra S, Holberg CJ, Guilbert TW, et al. Outcome of asthma and wheezing in the first 6 years of life: follow-up through adolescence. Am J Respir Crit Care Med. 2005;172(10):1253-8.

8. Lowe L, Murray CS, Custovic A, Simpson BM, Kissen PM, Woodcock A, et al. Specific airway resistance in 3-year-old children: a prospective cohort study. Lancet. 2002;359(9321): 1904-8.

9. Freidhoff LR, Marsh DG. Relationship among asthma, serum $\lg \mathrm{E}$ and skin test sensitivity to inhaled allergens. Int Arch Allergy Immunol. 1993; 100(4):355-61.

10. Sears MR, Burrows B, Flannery EM, Herbison GP, Hewitt CJ, Holdaway MD. Relation between airway responsiveness and serum $\lg E$ in children with asthma 
and in apparently normal children. $\mathrm{N}$ Engl $\mathrm{J}$ Med. 1991;325(15):1067-71.

11. Burrows B, Martinez FD, Halonen M, Barbee RA, Cline MG. Association of asthma with serum $\lg E$ levels and skin-test reactivity to allergens. $\mathrm{N}$ Engl J Med. 1989;320(5):271-7.

12. Peat JK, Salome CM, Woolcock AJ. Longitudinal changes in atopy during a 4-year period: relation to bronchial hyperresponsiveness and respiratory symptoms in a population sample of Australian school children. J Allergy Clin Immunol. 1990;85(1 Pt 1):65-74.

13. Sherrill DL, Stein R, Halonen M, Holberg CJ, Wright A, Martinez FD. Total serum $\lg E$ and its association with asthma symptoms and allergic sensitization among children. J Allergy Clin Immunol. 1999;104(1):28-36.

14. Illi S, von Mutius E, Lau S, Nickel R, Niggemann B, Sommerfeld C, et al. The pattern of atopic sensitization is associated with the development of asthma in childhood. J Allergy Clin Immunol. 2001;108(5):70914.

15. Stein RT, Sherrill D, Morgan WJ, Holberg CJ, Halonen M, Taussig LM, et al. Respiratory syncytial virus in early life and risk of wheeze and allergy by age 13 years. Lancet. 1999;354(9178):541-5.

16. Pereira MU, Sly PD, Pitrez PM, Jones MH, Escouto D, Dias AC, et al. Nonatopic asthma is associated with helminth infections and bronchiolitis in poor children. Eur Respir J. 2007;29(6):1154-60.

17. Lin BK, Clyne M, Walsh M, Gomez O, Yu W, Gwinn M, et al. Tracking the epidemiology of human genes in the literature: the HuGE Published Literature database. Am J Epidemiol. 2006;164(1):1-4.

18. Howard TD, Koppelman GH, Xu J, Zheng SL, Postma DS, Meyers DA, et al. Gene-gene interaction in asthma: IL4RA and IL13 in a Dutch population with asthma. Am J Hum Genet. 2002;70(1):230-6.

19. Heinzmann A, Mao XQ, Akaiwa M, Kreomer RT, Gao PS, Ohshima K, et al. Genetic variants of $1 \mathrm{~L}-13$ signalling and human asthma and atopy. Hum Mol Genet. 2000;9(4):549-59.

20. Kabesch M, Tzotcheva 1, Carr D, Hofler C, Weiland SK, Fritzsch C, et al. A complete screening of the ll4 gene: novel polymorphisms and their association with asthma and $\lg \mathrm{E}$ in childhood. J Allergy Clin Immunol. 2003;112(5):893-8.

21. Kabesch M, Schedel M, Carr D, Woitsch B, Fritzsch C, Weiland SK, et al. IL-4/IL-13 pathway genetics strongly influence serum $\operatorname{lgE}$ levels and childhood asthma. J Allergy Clin Immunol. 2006;117(2):269-74.

22. Fujimura M, Xiu Q, Tsujiura M, Tachibana H, Myou S, Matsuda T, et al. Role of leukotriene B4 in bronchial hyperresponsiveness induced by interleukin-8. Eur Respir J. 1998;11(2):306-11.

23. Xiu Q, Fujimura M, Nomura M, Saito M, Matsuda T, Akao N, et al. Bronchial hyperresponsiveness and airway neutrophil accumulation induced by interleukin- 8 and the effect of the thromboxane A2 antagonist S-1452 in guinea-pigs. Clin Exp Allergy. 1995; 25(1):51-9.

24. Kurashima K, Mukaida N, Fujimura M, Schroder JM, Matsuda T, Matsushima K. Increase of chemokine levels in sputum precedes exacerbation of acute asthma attacks. J Leukoc Biol. 1996; 59(3):313-6.

25. Amin K, Lúdvíksdóttir D, Janson C, Nettelbladt 0 , Björnsson E, Roomans GM, et al. Inflammation and structural changes in the airways of patients with atopic and nonatopic asthma. BHR Group. Am J Respir Crit Care Med. 2000;162(6):2295-301.

26. Kimata H, Lindley 1, Furusho K. Selective inhibition of spontaneous $\lg \mathrm{E}$ and $\lg \mathrm{G} 4$ production by interleukin-8 in atopic patients. Blood. 1995;85(11):3191-8.

27. Kimata H, Yoshida A, lshioka C, Lindley 1, Mikawa H. Interleukin 8 (IL-8) selectively inhibits immunoglobulin E production induced by lL-4 in human B cells. J Exp Med. 1992;176(4):1227-31.

28. Sigurs N, Gustafsson PM, Bjarnason R, Lundberg F, Schmidt S, Sigurbergsson F, et al. Severe respiratory syncytial virus bronchiolitis in infancy and asthma and allergy at age 13. Am J Respir Crit Care Med. 2005;171(2):137-41.

29. Sigurs N, Bjarnason R, Sigurbergsson F, Kjellman B. Respiratory syncytial virus bronchiolitis in infancy is an important risk factor for asthma and allergy at age 7 . Am J Respir Crit Care Med. 2000;161(5):1501-7.

30. Norzila MZ, Fakes K, Henry RL, Simpson J, Gibson PG. Interleukin-8 secretion and neutrophil recruitment accompanies induced sputum eosinophil activation in children with acute asthma. Am J Respir Crit Care Med. 2000; 161:769-74

31. Heinzmann A, Ahlert 1, Kurz T, Berner R, Deichmann KA. Association study suggests opposite effects of polymorphisms within IL8 on bronchial asthma and respiratory syncytial virus bronchiolitis. J Allergy Clin Immunol. 2004;114(3):671-6.

32. Hull J, Ackerman H, lsles K, Usen S, Pinder M, Thomson A, et al. Unusual haplotypic structure of IL8, a susceptibility locus for a common respiratory virus. Am J Hum Genet. 2001;69(2):413-9.

33. Hull J, Thomson A, Kwiatkowski D. Association of respiratory syncytial virus bronchiolitis with the interleukin 8 gene region in UK families. Thorax. 2000;55(12):1023-7.

34. Puthothu B, Krueger M, Heinze J, Forster J, Heinzmann A. Impact of $1 \mathrm{~L} 8$ and IL8-receptor alpha polymorphisms on the genetics of bronchial asthma and severe RSV infections. Clin Mol Allergy. 2006;17;4:2.

35. Lu AZ, Wang LB, Zhang MZ, Zhang XB. Association of interleukin 8 single nucleotide polymorphisms with the susceptibility to respiratory syncytial virus infection. Zhonghua Er Ke Za Zhi. 2007; 45(2):100-4

36. Leung TF, Tang NL, Sung YM, Li AM, Wong GW, Chan IH, et al. The $\mathrm{C}-159 \mathrm{~T}$ polymorphism in the CD14 promoter is associated with serum total $\lg \mathrm{E}$ concentration in atopic Chinese children. Pediatr Allergy Immunol. 2003;14(4):255-60.

37. Bucková D, Hollá Ll, Schüller M, Znojil V, Vácha J. Two CD14 promoter polymorphisms and atopic phenotypes in Czech patients with lgE-mediated allergy. Allergy. 2003;58(10):1023-6.

38. Kabesch M, Hasemann K, Schickinger V, Tzotcheva l, Bohnert A, Carr D et al. A promoter polymorphism in the CD14 gene is associated with elevated levels of soluble CD14 but not with $\operatorname{lgE}$ or atopic diseases. Allergy. 2004;59(5):520-5.

39. Leynaert B, Guilloud-Bataille M, Soussan D, Benessiano J, Guénégou A, Pin 1, et al. Association between farm exposure and atopy, according to the CD14 C-159T polymorphism. J Allergy Clin Immunol. 2006;118(3):65865.

40. Koppelman GH, Reijmerink NE, Colin Stine 0, Howard TD, Whittaker PA, Meyers DA, et al. Association of a 
promoter polymorphism of the CD14 gene and atopy. Am J Respir Crit Care Med. 2001;163(4):965-9.

41. Liu X, Beaty TH, Deindl P, Huang SK, Lau S, Sommerfeld $C$ et al. Associations between total serum lgE levels and the 6 potentially functional variants within the genes IL4, IL13, and IL4RA in German children: the German Multicenter Atopy Study. J Allergy Clin Immunol. 2003;112(2):382-8.

42. leung TF, Tang NL, Chan IH, Li AM, Ha G, Lam CW. A polymorphism in the coding region of interleukin-13 gene is associated with atopy but not asthma in Chinese children. Clin Exp Allergy. 2001; 31(10):1515-21.

43. Howard TD, Whittaker PA, Zaiman AL, Koppelman GH, $\mathrm{Xu}$ J, Hanley MT, et al. Identification and association of polymorphisms in the interleukin-13 gene with asthma and atopy in a Dutch population. Am J Respir Cell Mol Biol. 2001;25(3):377-84.

44. Nieters A, Linseisen J, Becker N. Association of polymorphisms in Th1, Th2 cytokine genes with hayfever and atopy in a subsample of EPIC-Heidelberg. Clin Exp Allergy. 2004;34(3):346-53.

45. Ober C, Leavitt SA, Tsalenko A, Howard TD, Hoki DM, Daniel R, et al. Variation in the interleukin 4-receptor alpha gene confers susceptibility to asthma and atopy in ethnically diverse populations.Am J Hum Genet. 2000;66(2):517-26.

46. Deichmann KA, Heinzmann A, Forster J, Dischinger S, Mehl C, Brueggenolte E, et al. Linkage and allelic association of atopy and markers flanking the IL4-receptor gene. Clin Exp Allergy. 1998;28(2):151-5.

47. Isidoro-García M, Dávila I, Laffond E, Moreno E, Lorente F, González-Sarmiento R. Interleukin-4 (IL4) and Interleukin-4 receptor (IL4RA) polymorphisms in asthma: a case control study. Clin Mol Allergy. 2005;3:15.

48. Kruse S, Japha T, Tedner M, Sparholt SH, Forster J, Kuehr J, et al. The polymorphisms S503P and Q576R in the interleukin-4 receptor alpha gene are associated with atopy and influence the signal transduction. Immunology. 1999;96(3):365-71.

\section{About the authors}

\section{Leonardo Araujo Pinto}

Professor. Pontificia Universidade Católica do Rio Grande do Sul - PUCRS, Pontifical Catholic University of Rio Grande do Sul Porto Alegre, Brazil.

\section{Renato Tetelbom Stein}

Professor. Pontificia Universidade Católica do Rio Grande do Sul - PUCRS, Pontifical Catholic University of Rio Grande do Sul Porto Alegre, Brazil.

\section{José Dirceu Ribeiro}

Professor. Universidade Estadual de Campinas - Unicamp, State University at Campinas - Campinas, Brazil. 